\title{
Creativity and Entrepreneurial Tendencies Among Form Two Malaysian Students
}

\begin{abstract}
The aim of this study is to design a reliable and valid instrument to assess entrepreneurial tendency and to investigate the relationship of entrepreneurial tendency and creative personality among form two Malaysian students. A sample of 174 form two students taking entrepreneurship as a subject were chosen randomly from the four zones in Malaysia. The validated Entrepreneurship Tendency Inventory (ETI) and a measure of creative personality characteristics, Khatena Torrance Creative Perception Inventory (KTCPI) were administered. Factor analysis revealed the existence of eight factors namely, self-employed, business confidence, business intention, business anxiety, people dependent, forced decision, low selfconfidence and contingent decision with internal consistencies ranging from 0.80 (selfemployed) to 0.23 (low self-confidence). Self-employed, business confidence, business intention and people dependent are found to relate positively to entrepreneurial tendency. Business Anxiety has a very low correlation with entrepreneurial tendency. Students who perceive themselves as creative based on past creative performances have high levels of initiative, place more importance on what close relatives think and prefer challenging tasks and tend to have higher entrepreneurial tendencies. Further replication of this study is recommended to confirm the reliability and validity of ETI and to further elucidate the relationship between entrepreneurial tendencies and creative personality characteristics
\end{abstract}

Keyword: Entrepreneurial tendency, creative perception, khatena-torrance creative perception inventory 